\title{
Prevalence and Associated Factors of Depression among Elderly Population Living in Geriatric Homes in Kathmandu Valley
}

\author{
Choulagai P S, Sharma C K, Choulagai B P \\ Tribhuvan University, Institute of Medicine, Nursing Campus Maharajgunj and Maharajgunj Medical Campus, \\ Maharajgunj, Kathmandu
}

Correspondence address: Poojan Sharma Choulagai, Tribhuvan University, Institute of Medicine, Nursing Campus Maharajgunj, Kathmandu

Email: poojan42@gmail.com

\begin{abstract}
Introduction: Depression generally presents in all age group but is more common among elderly population living in geriatric homes. Despite the growth of geriatric home health services, little is known about the mental health needs of geriatric people seen in their homes.

Methods: This study is conducted in July - December 2010 to determine the prevalence and associated factors of depression among elderly population living in geriatric homes in Kathmandu Valley. A total of 78 elderly people were included in this study. Semi-structured questionnaires and in-depth interview guidelines were used to further exploring the associated factors of depression. The study participants were identified by using Geriatric Depression Scale.

Results: The prevalence of depression was 51.3\% with severe depression $15.4 \%$ and mild depression $35.9 \%$. Most of the severely depressed respondents (75\%) were widow/widower; most of the mild depressed respondents $(85.7 \%)$ were illiterate; three quarter $(75 \%)$ of severely depressed respondents had no children; and almost all of severely depressed respondents $(90.9 \%)$ had difficulty in daily living activities due to health problems.

Conclusion: Majority of respondents were found to be living with varying level of depression. Poverty, presence of physical illness and lacking social and family support contributes to depression. Majority of depressed respondents mentioned their satisfaction with the living in geriatric home.
\end{abstract}

Key words: Elderly population, geriatric home, depression

\section{Introduction}

Psychiatric disorders are especially prevalent among elderly. Out of the psychiatric disorders amongst the elderly, depression is one of the most frequent and debilitating mental disorders, with a world-wide prevalence of about $10-15 \%$. Further adding to this problem, depression in the elderly is often undiagnosed or untreated. ${ }^{1}$ With a greater percentage of people living beyond the age of 60 in both the developed and the developing countries, the problem of mental illness among the elderly has grown significantly. ${ }^{2}$ Depression among institutionalized elderly is an important timely issue often undiagnosed and untreated, which needs to be addressed. ${ }^{3}$ People with low self-esteem and a pessimistic outlook on life, seem to be particularly prone to depression ${ }^{4}$.

Social isolation is one of the important factors causing depression in the elderly, and it may come on due to retirement and lack of social contact, or due to physical illness and inability to move about, or due to the children moving away from the family for reason of employment or marriage. Depression occurring in subjects living alone 
and having poor family contacts is particularly dangerous, as they may not seek treatment and may attempt suicide. ${ }^{5}$ Depression typically results from such losses as deaths of friends and loved ones, loss of physical capacities, loss of social status and self esteem. Bereavement is an important risk factors for elderly depression. Roughly $10 \%$ to $20 \%$ of widows and widowers develop clinically significant depression during the first year of bereavement. ${ }^{6}$

\section{Methods}

The study was cross-sectional and descriptive type. It was conducted in five geriatric homes of Kathmandu Valley which included Nishahaya Sewa Sadan Shantinagar Baneshwor, Kathmandu, Dev Corner Sewa Samiti Godawari, Lalitpur, Divine Services Home Golfutar Kathmandu, Matatirtha Briddhashram Samiti, Matatirtha Kathmandu, and Tapasthali Briddhashram, Chapali, Kathmandu. The study duration was five months (July - Dec 2010) with 4 weeks in field.

Geriatric Depression Scale is a tool used to screen depression in elderly developed by J.A. Yesavage and others in $1982 .{ }^{7}$ It is a brief questionnaire in which study participants are asked to respond to the 30 questions by answering yes or no in reference to how they felt on the day of administration. Scores of 0-9 are considered normal, 10-19 indicate mild depression and 20-30 indicate severe depression. Geriatric Depression scale is available in English language. For this study the scale was translated in Nepali by a clinical psychologist. After translating into Nepali, back-translation into English was done by another translator and tallied both previous original scales with new English scale.

The five geriatric homes were purposively selected. All the elderly people from selected geriatric home were screened for depression by using geriatric depression scale and all the depressed respondents were included in the study. A total of 78 respondents were accessed for study purpose. The in-depth interview was conducted with 11 respondents.

Open responses from respondents were coded by developing coding manual then data were entered in database created in SPSS. Responses of in depth interview were analyzed by using theme analysis.

\section{Results}

All available 78 respondents were screened and among them 40 (51.3\%) had depression. The overall prevalence of depression was $51.3 \%$ with severe depression $15.4 \%$ and mild depression $35.9 \%$

Most of the respondents (32.5\%) were of age group 75 to 79 years. Majority of respondents (95\%) were female. The caste distribution among the respondents was Brahmin/Chhetri 50\%, Newar 35\%, Lama/Tamang 10\%, Thakuri 2.5\% and Sanyasi $2.5 \%$. Almost all of the respondents (90\%) were illiterate. Half of the respondents (50\%) were unemployed at the time of coming to geriatric centre. More than two third respondents $(67.5 \%)$ were widow/widower, $12.5 \%$ were separated, $10 \%$ were unmarried and $7.5 \%$ divorced.

More than half of the participants (57.5\%) were living permanently in Kathmandu valley as depicted in demographic information of respondents (table 1).

\section{Level of depression by marital status}

Three in every four severely depressed respondents (75\%) were widow/widower. About one in every six severely depressed respondents $(16.7 \%)$ were separated and nearly one in every twelve severely depressed respondents $(8.3 \%)$ were married. 
Table 1: Demographic Information of the respondents with depression.

\begin{tabular}{|c|c|c|c|}
\hline Characteristics & & Frequency & Percent \\
\hline \multirow[t]{7}{*}{ Age (in years) } & 60 to 64 years & 4 & 10 \\
\hline & 65 to 69 years & 6 & 15 \\
\hline & 70 to 74 years & 6 & 15 \\
\hline & 75 to 79 years & 13 & 32.5 \\
\hline & 80 to 84 years & 7 & 17.5 \\
\hline & 85 to 89 years & 1 & 2.5 \\
\hline & 90 years and above & 3 & 7.5 \\
\hline \multirow[t]{2}{*}{ Gender } & Female & 38 & 95 \\
\hline & Male & 2 & 5 \\
\hline \multirow[t]{5}{*}{ Caste } & Brahmin/Chhetri & 20 & 50 \\
\hline & Newar & 14 & 35 \\
\hline & Lama/Tamang & 4 & 10 \\
\hline & Thakuri & 1 & 2.5 \\
\hline & Sanyasi & 1 & 2.5 \\
\hline \multirow[t]{5}{*}{ Marital Status } & Married & 1 & 2.5 \\
\hline & Unmarried & 4 & 10 \\
\hline & Widow/widower & 27 & 67.5 \\
\hline & Divorced & 3 & 7.5 \\
\hline & Separated & 510 & 12.5 \\
\hline \multirow[t]{4}{*}{ Education } & Illiterate & 36 & 90 \\
\hline & Literate & 2 & 5 \\
\hline & 1 to 5 class & 1 & 2.5 \\
\hline & 6 to 10 class & 1 & 2.5 \\
\hline \multirow[t]{5}{*}{ Occupation } & Unemployed & 20 & 50 \\
\hline & Housewife & 5 & 12.5 \\
\hline & Farming & 9 & 22.5 \\
\hline & Service & 1 & 2.5 \\
\hline & Others & 5 & 12.5 \\
\hline \multirow[t]{2}{*}{ Permanent Residence } & Kathmandu valley & 23 & 57.5 \\
\hline & Outside Kathmandu valley & 17 & 42.5 \\
\hline
\end{tabular}

Table 2: Level of depression by marital status

\begin{tabular}{llll} 
Marital Status & \multicolumn{2}{l}{ Level of depression } & Total \\
& $\begin{array}{l}\text { Mild } \\
\text { depression }\end{array}$ & $\begin{array}{l}\text { Severe } \\
\text { depression }\end{array}$ & \\
\hline Widow/widower & $18(64.3 \%)$ & $9(75 \%)$ & 27 \\
\hline Unmarried & $4(14.3 \%)$ & $0(0 \%)$ & 4 \\
\hline Divorced & $3(10.7 \%)$ & $0(0 \%)$ & 3 \\
\hline Separated & $3(10.7 \%)$ & $2(16.7 \%)$ & 5 \\
\hline Married & $0(0 \%) 1$ & $(8.3 \%)$ & 1 \\
\hline Total & 28 & 12 & 40
\end{tabular}




\section{Depression Status by education level}

Most of the mild depressed respondents (85.7\%) were illiterate and only $3.6 \%$ mild depressed were completed primary education. All the severely depressed respondents $(100 \%)$ were illiterate.

Table 3: Depression status by educational level

\begin{tabular}{|c|c|c|c|}
\hline Level of & \multicolumn{2}{|c|}{ Level of depression } & Total \\
\hline Education & $\begin{array}{l}\text { Mild } \\
\text { depression }\end{array}$ & $\begin{array}{l}\text { Severe } \\
\text { depression }\end{array}$ & \\
\hline Illiterate & $24(85.7 \%)$ & $12(100 \%)$ & $36(90 \%)$ \\
\hline Literate & $2(7.1 \%)$ & $0(0 \%)$ & $2(5 \%)$ \\
\hline 6 to 10 class & $1(3.6 \%)$ & $0(0 \%)$ & $1(2.5 \%)$ \\
\hline 1 to 5 class & $1(3.6 \%)$ & $0(0 \%)$ & $1(2.5 \%)$ \\
\hline Total & $28(100 \%)$ & $12(100 \%)$ & $40(100 \%)$ \\
\hline
\end{tabular}

Table 4: Level of depression by type of Family

\begin{tabular}{llll}
$\begin{array}{l}\text { Type of } \\
\text { family }\end{array}$ & \multicolumn{2}{l}{$\begin{array}{l}\text { Level of depression } \\
\text { Mild }\end{array}$} & \multicolumn{1}{l}{ Severe } \\
depression & depression & \\
\hline Living & & & \\
\hline alone & $17(60.7 \%)$ & $6(50.0 \%)$ & $23(57.5 \%)$ \\
\hline Living in & & & $17(42.5 \%)$ \\
family & $11(39.3 \%)$ & $6(50 \%)$ & $40(100.0 \%)$ \\
\hline Total & $28(100.0 \%)$ & $12(100.0 \%)$ &
\end{tabular}

\section{Level of depression by type of family}

Out of 28 mild depressed respondents, 17 (60.7\%) were living alone, and 11 (39.3\%) were living in family Half of the severely depressed respondents (50\%) were living alone and half (50\%) were living in family before coming to geriatric centre.

$\chi \mathrm{df1} 2=0.394$

There was no statistically significant association between level of depression and type of family before coming to geriatric home.

\section{Level of depression by difficulties faced due to health problems}

Any alteration in health may create difficulty in adjustment and may develop depression. Elderly in geriatric home are facing various health problems including physical and mental. Due to those problems, almost all of severely depressed respondents $(90.9 \%)$ and nearly four in every five mild depressed respondents $(77.3 \%)$ had difficulty in daily living activities.

Table 5: Level of depression by difficulties faced due to health problem

\begin{tabular}{|llll|}
\hline \multirow{2}{*}{$\begin{array}{l}\text { Difficulties facing due to health problem } \\
\text { Difficulty in daily living activities }\end{array}$} & \multicolumn{2}{c}{ Level of depression } & Total \\
\hline Could not sleep well 2 & $17(77.3 \%)$ & $10(90.9 \%)$ & $27(81.8 \%)$ \\
\hline could not go anywhere & $(9.1 \%)$ & $0(0 \%)$ & $2(6.1 \%)$ \\
\hline could not eat favorite food & $0(0 \%)$ & $1(9.1 \%)$ & $1(3.0 \%)$ \\
\hline Total & $3(13.6 \%)$ & $0(0 \%)$ & $3(9.1 \%)$ \\
\hline
\end{tabular}

\section{Discussion}

Depression is one of the mental health problems seen in geriatric population. It develops due to maladjustment in presence of stress factors. At least $15-20 \%$ of the elderly in the general population may experience depression. ${ }^{8}$ A systematic review of community based studies found on average prevalence of clinically relevant depression of $13.5 \%$ for those aged 55 or over, 
of which $9.8 \%$ was classed as minor and $1.8 \%$ as major. ${ }^{9}$ In present study, the prevalence of depression among elderly is $51.28 \%$. The prevalence of mild depression is $35.89 \%$ and prevalence of severe depression is $15.38 \%$. Therefore present study findings are consistent with the above literature.

Poverty and physical ill-health are risk factors for depression among elderly while good social support is protective. ${ }^{10}$ In present study $64.3 \%$ mild depressed respondents and $66.7 \%$ severely depressed respondents were unemployed before coming to geriatric center. And $82.5 \%$ elderly had physical illnesses. They suffered from orthopedic problems, gastrointestinal problems, eye problems, metabolic problems and respiratory problems. Due to physical health problems they were facing difficulties in daily living activities. For treatment they had no enough money and family was not supportive to them. Unsupportive family was a major cause for maladjustment to elderly resulting in depression. Therefore present study findings are consistent with the above literature.

Levels of education also determine the depression in elderly people. Perception of problem and coping strategy may depend on education level of person. In present study, all the severely depressed respondents $(100 \%)$ were illiterate.

In every step of life, support of family is important for people to stay mentally healthy. Every persons need love and care in every stages of life. If a person is alone and family is not supportive then he or she may suffer from mental illness. A study on "Anxiety and Depression in Lone Elderly Living at Their own Homes \& Going to Geriatric Clubs Versus Those Living at Geriatric Homes" has been done in 2005. The aim of this study is to evaluate the prevalence of anxiety \& depression in lone elderly living at their own homes \& going to geriatric clubs regularly or living at geriatric homes. Living at geriatric homes and age group 60 to 70 are independent risk factors for anxiety, depression or mixed anxiety. ${ }^{11}$ In present study, $60.7 \%$ mild depressed respondents were living alone before coming to geriatric home. Therefore present study findings are consistent with the above literature.

Many elderly adults face significant life changes and stressors that put them at risk for depression. Those at the highest risk include older adults with a personal or family history of depression, failing health, substance abuse problems, or inadequate social support. ${ }^{12}$ Although there were many elderly people they were found feeling of loneliness in geriatric home. In present study, 55.6\% elderly had not support of their children. They always remember their family although the family is not supportive. Elderly were worry about their children and grandchildren. They feel unlucky regarding living in geriatric home and they always think about their funeral. They said that they always think how their funeral will be done. The pattern of relationship to spouse was explored by asking open ended question. More than half of severely depressed respondents $(58.3 \%)$ and mild depressed respondents (54.2\%) had satisfactory relationship with their spouse. Moving from family and living alone are major predisposing factor for depression seen in present study

Half of depressed respondents (50\%) had previous depression. Almost all depressed respondents (87.5\%) had no history of mental illness in their family and only few depressed respondents $(12.5 \%)$ had history of mental illness in their family.

Overall satisfaction for living in geriatric home was explored regarding foods, lodging, and leisure time activities. Mild depressed respondents $(92.5 \%)$ and majority of severe depressed respondents $(83.3 \%)$ were satisfied for living in geriatric home. Some of elderly were not satisfied in foods given there.

In the quantitative meta-analysis, bereavement, sleep disturbance, disability, prior depression, and female gender were significant risk factors. ${ }^{9}$ Factors that increase the risk of depression in the elderly include being female, being single, lack of family and social support, stressful events in life, poor economic status, illiteracy and presence of physical illnesses.

\section{Conclusion}

The prevalence of depression is found in more than half of the respondents. Increasing age, being female and situational and developmental crisis is associated with elderly depression. Poverty, presence of physical illness and lacking social and family support contributes to depression. Presence of previous depression contributes to occurrence of depression in elderly and living alone, after death of spouse is factors contributing to depression when they are neglected and unsupported by their children.

Levels of education also determine the depression in elderly people. Perception of problem and coping strategy may be depends on education level of person. Presence of children is not associated to elderly depression, but getting support from family members is found to help reduce the level of depression. Majority of depressed respondents mentioned their satisfaction with the living in geriatric home.

Conflict of interest: The authors declare that they have no conflict of interests. 


\section{References}

1. Gelder M, Mayou R, Geddes J. Oxford Core Text of Psychiatry. 2nd ed. Oxford: Oxford University Press; 1999.

2. David CS. Prevalence of Depression and its Treatment in an Elderly Population: Archives of General Psychiatry, 2000; 57: 601-607.

3. Wijeratne M D M, Wijerathne S A, Wijesekara S G, Wijesingha I. Prevalence of depression among institutionalized elders in the Colombo district 2000; 27-31, www.med.cmb.ac.lk.

4. Donald MC YG, Franklin ERD, Psychiatric illnesses in Elderly. Journal of Gerontology.1992; 47:142-150.

5. Vyas JN and Ahuja N. Textbook of Postgraduate Psychiatry; 2nd ed; New Delhi, Jaypee brothers medical publishers (p) LTD (1999).

6. Tracy S. Diehl. Disorder of the elderly Psychiatric Nursing; Philadelphia, Lippincott Williams and Wilkins; 2004.

7. Wikipedia, The Free Encyclopedia. Geriatric Depression Scale. http://en.wikipedia.org/wiki/ Geriatric Depression Scale.

8. Sadock BJ, Sadock VA. Kaplan and Sadock's Comprehensive Textbook of psychiatry, 7th ed, Philadelphia, Lippincott Williams and Wilkins, 2000.

9. Martin G, Dendukuri N. Risk Factors for Depression Among Elderly Community Subjects: A Systematic Review and Meta-Analysis. The American Journal of psychiatry 2001; 160:1147-56.

10. Rajkumar A.P., Thangadurai P., Senthikumar P. Gayathri K, Prince M, Jacob K S. Int Psychogeriatr. 2009 April; 21(2): 372-378.

11. Tomader Taha Abdel Rahman, Ain Shams University Cairo, Egypt Anxiety and Depression in Lone Elderly Living at Their own Homes and Going to Geriatric Clubs Versus Those Living at Geriatric Homes or Anxiety and Depression in Lone Elderly 2006.globalaging.org/ health/world/2006/egyptelderly.pdf. (accessed July 20, 2010)

12. Gelder M. Paul H. Cowen P. Shorter Oxford Textbook of Psychiatry, 5th ed. United Kingdom, Oxford University Press, 2010. 